\title{
An Economic Analysis of Non-Performing Assets of Banks in India
}

\author{
Sankara Narayanan. K
}

\begin{abstract}
Banking and Financial Institutions are the strength of any countries economy and which plays an important role to the progress to the country. With an increase in the prerequisite of banking systems in the trade and industry development progression, the major challenge that the Bank and the Financial Institutions are facing an increase in Non-Performing Assets. The Central Bank of India (RBI) instructed all the banks to stringent the loan process to avoid the increase in NPA, which is still peaking high every year. According to the credit rating agency CRISIL, the gross NPA (GNPA) has touched almost Rs. 8,06,412 crore as on 31.3.2019 (provisional data). As per RBI provisional data on comprehensive procedures, as on 31.3.2019, the cumulative amount of unrefined NPAs of PSBs and Scheduled Commercial Banks (SCBs) were Rs. 8,06,412 crore and Rs. 9,49,279 crore correspondingly. Numerous wise accounting norms with a focus to NPA have been introduced by the RBI to diminish the Non-Performing Assets. Consequently, to progress the financial health of a banking system Non-Performing Assets management has become an important assignment of the bank. Over the last five years, Government has engaged wide-ranging phases under its $4 R$ 's approach of recognizing NPAs evidently, undertaking and improving value from strained books, recapitalizing PSBs, and transformations in banks and financial system to guarantee a liable besides spot less structure.
\end{abstract}

Keywords : NPA, Economic Slowdown, Bad debts, Net worth..

\section{INTRODUCTION}

In an emerging country like India the banking and financial sector is considered as a tool of progress and dynamically contribute to the nation. Banking and Financial Services Industry (BFSI) is one of the critical facets of an economy and it is in its great spell in the banking segment. Many arrangements like Jan Dhan, Direct transfer, make in India all these requires the Indian banking system to improve its spectrum to provide a hitch less service. However the steps towards accomplishing the vision many of the banks are really worried about the perennial issue of the NPA will be the principal issue to handle as for as the growth is alarmed.

Non-Performing Asset or a stressed Loan is nothing but a loan or an account of a debtor, which has been designated by the bank or the financial institutions as a suspicious account or a loss in line with the guiding principle of the Central Bank (RBI). Though RBI imposed the stringent rules against the NPA, the banks are also advised to declare the NPA. This has resulted to create a provisioning for bad loans, which result in reducing profit and creating adverse emotion for the banking and financial industry. Identifying the NPA is becoming the stressful job to the bankers and leading to the unhealthy financial situation which is causing the economic crisis. Typically the bank's health condition can be calculated using the NPA ratio. Now days the public banks are under huge financial stress which is due to the accumulated non-performing assets, it is mandatory to take the necessary steps to reduce the financial stress of a BFSI industry. The remedial steps will help them in planning to avoid the future bad loans.

In general, the assets are classified as Standard assets, substandard assets, doubtful and lost assets. Apart from the standard assets all other assets will be termed as Non-Performing Assets (NPA). Again the NPA can be categorized into Gross NPA (GNPA) and Net NPA (NNPA). In general the Gross NPA can be defined as the sum of total of all the loan possessions that are categorized as NPA as per the RBI recommendations as on date in the Balance sheet.

\section{LITERATURE REVIEW}

Many of the researchers have tried myriad quantity of times to predict the performance of the bank based on the Non-Performing Loans. The scale of NPA is moderately complex in PSU's than private banks (Singh, 2013). A great of amount of bad loans too proposes the possibility of a larger amount of bad debts and that affects the cost-effectiveness and liquidness of the banks. An analysis on schedules of bad loans in India on numerous copes explains how sheer credit of the badly-behaved and how proactive observing has been able to lessen the issue it to a prodigious level. On the identical route, the state sector banks in India which operates in a great extend to reduce the stressed accounts compared with the counterparts of the private banks in India. The literature recommends that the advancing strategies of many Banks and the financial institutions were not proper due to the competitions in the business.

Banks and the financial institutions should explain their lending policy to their clients and many of the BFSI does not give loans out of the country; this policy has to be leverage so that they can expand their business. A study on the macroeconomics empathizing the following variable and which is directly causing the GDP, the lending rate and the exchange rate of the country. 


\section{An Economic Analysis of Non-Performing Assets of Banks in India}

\section{RESEARCH ISSUES}

After the year 1991, Globalization policy opened doors to industrialists. This policy has created more risk, due to the uncertainty of the counterparty and the quality of the loans.

These NPAs has become a distress to the banks and which causes a huge set back in the Indian banking Industry.

There is a vast gap in the research on worth features of the Stressed Assets. All the researchers and the readings are trying to explicit the grounds, influence and the management view of NPAs. Bankers are really facing all-time issues to identify the right persons to disburse, which could affect the GDP and the economy. There is a need to understand the quantum of the NPAs to realize the issues in the banking industry. Due to the stringent rules in the banking sector that really affects accessing the money and employment opportunities.

\section{RESEARCH QUESTIONS}

1. Whether the NPAs are efficiently managed?

2. Do all the Banks are fronting the same trend on the NPAs.

3. Whether factor which drive the NPAs for the PSU's and the factors drive the NPA for the private banks are the same?

4. Whether the NPAs are more vulnerable towards the financial crisis?

5. How effectively the Loan recovery channels works like DRT, Lok Adalat, CDR and AMC's?

The primary intention of this research is to understand the factors which can enlighten the NPA and the discrepancy in the NPA among the banking Institutions. In addition to that, it helps us to analyze the initiatives taken to comprise the NPAs in a micro and the macro level. This analysis will help us to address the challenges in containing the NPAs in the Indian Banks and how effectively these NPAs can be handled. So the specific questions can be laid down to understand the necessity of analyzing the NPAs.

\section{OBJECTIVES}

An empirical effort is made through the current paper to appreciate the causes of the exponential growth Non
Performing Assets based on the following objectives.

1. To examine the trend of the NPA in Indian Banking sectors since 2005 .

2. To identify the causes for the NPA and its impression on the enactment of PSU Banks.

3. To estimate the causal association among the NPA and its determinants in India.

\section{IMPACT OF NPA ON BANKS}

Many of the banks are highly impacted negatively, due to the surge in NPA. The NPA could reduce the turnover of the bank and may pointers to the liquidation. The NPA may create a high risk to the bank; in turn it would lose the good will among their customers.

\section{SCOPE THE STUDY}

The scope of this analysis is to realize the current status of NPA in major ten banks for the last decade. It is to be noted that the trend may not be the same for all the banks and also for all the periods. The present study is related to the analysis for the financial years between 2005 to 2016 on the major public sector banks. This cannot be generalized for all other banks.

\section{SOURCES OF DATA}

For this study ten major banks have been chosen and the data related to the variables GNPA, EPS, Deposits, Total Assets, Total Advances, Total Income, Net Profit \& Net Profit per Share for the period 2005 to 2016. The data required for the analysis was gathered from the yearly report of RBI, to confine the aforesaid objectives and restricted to the boundaries of Public Sector Banks.

\section{DATA ANALYSIS AND ELUCIDATION}

Below table explains the total amount of loan disbursed in the major Public sector banks and its Priority \& non priority sector. The loan disbursal volume is significantly increased over a period years. Among the three sectors the Non Priority sector has been grown expressively during the years 2005 2016. The trend graph explains the overall growth of the loan disbursal and the percentage of the defined sectors individually.

Trend graph of Loan disbursal during the period 2005-2016

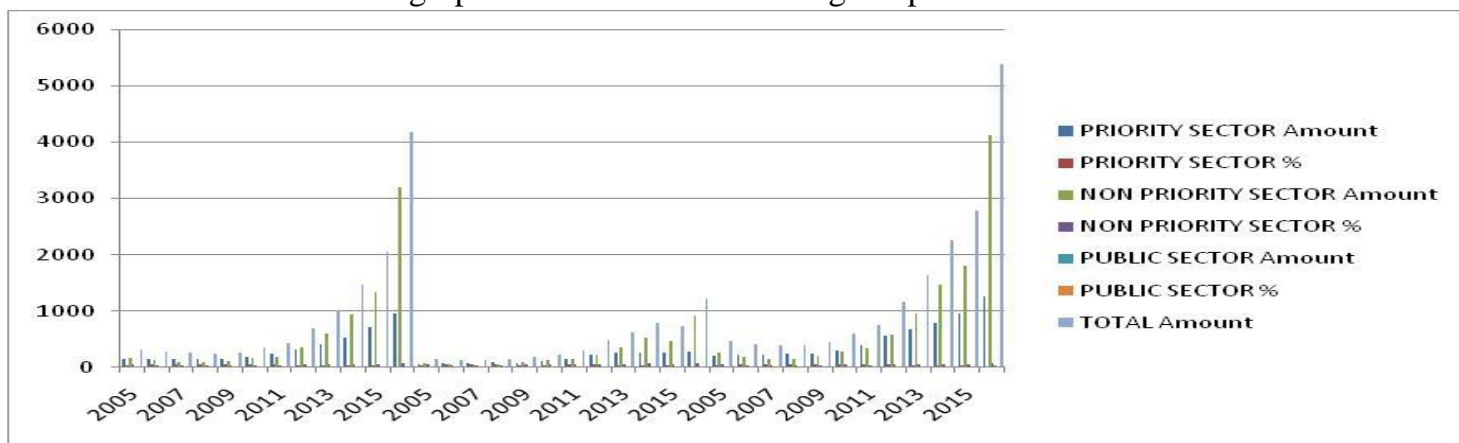


Table - 1: Loan Amount disbursed for the period of 2005 - 2016.

\begin{tabular}{|c|c|c|c|c|c|c|c|}
\hline \multirow[t]{2}{*}{ Bank Group/Years } & \multicolumn{2}{|c|}{ PRIORITY SECTOR } & \multicolumn{2}{|c|}{$\begin{array}{l}\text { NON PRIORITY } \\
\text { SECTOR }\end{array}$} & \multicolumn{2}{|c|}{ PUBLIC SECTOR } & \multirow{2}{*}{$\frac{\text { TOTAL }}{\text { Amount }}$} \\
\hline & Amount & $\%$ & Amount & $\%$ & Amount & $\%$ & \\
\hline \multicolumn{8}{|l|}{ Nationalized Banks } \\
\hline 2005 & 153.36 & 46.75 & 170.62 & 52.01 & 4.06 & 1.24 & 328.04 \\
\hline 2006 & 149.22 & 51.78 & 132.27 & 45.9 & 6.68 & 2.32 & 288.17 \\
\hline 2007 & 153.44 & 58.63 & 103.4 & 39.51 & 4.87 & 1.86 & 261.72 \\
\hline 2008 & 159.72 & 63.96 & 85.63 & 34.29 & 4.38 & 1.76 & 249.74 \\
\hline 2009 & 157.54 & 59.35 & 106.68 & 40.19 & 1.21 & 0.46 & 265.43 \\
\hline 2010 & 195.67 & 53.76 & 165.23 & 45.4 & 3.05 & 0.84 & 363.95 \\
\hline 2011 & 246.2 & 55.61 & 194.1 & 43.84 & 2.42 & 0.55 & 442.72 \\
\hline 2012 & 324.24 & 46.96 & 355.55 & 51.49 & 10.68 & 1.55 & 690.48 \\
\hline 2013 & 408.34 & 40.16 & 599.01 & 58.91 & 9.48 & 0.93 & 1016.83 \\
\hline 2014 & 537.5 & 36.45 & 935.67 & 63.46 & 1.3 & 0.09 & 1474.48 \\
\hline 2015 & 709.34 & 34.61 & 1337.67 & 65.26 & 2.59 & 0.13 & 2049.59 \\
\hline 2016 & 969.03 & 23.18 & 3210.85 & 76.82 & 17.63 & 0.42 & 4179.88 \\
\hline \multicolumn{8}{|c|}{ State Bank of India \& Associates } \\
\hline 2005 & 62 & 41.84 & 84.31 & 56.9 & 1.86 & 1.26 & 148.18 \\
\hline 2006 & 73.14 & 58.27 & 50.52 & 40.25 & 1.87 & 1.49 & 125.52 \\
\hline 2007 & 71.75 & 56.57 & 52.63 & 41.49 & 2.45 & 1.93 & 126.83 \\
\hline 2008 & 89.02 & 57.5 & 64.44 & 41.62 & 1.36 & 0.88 & 154.82 \\
\hline 2009 & 84.47 & 45.7 & 98.6 & 53.35 & 1.76 & 0.95 & 184.83 \\
\hline 2010 & 109.29 & 46.45 & 125.91 & 53.51 & 0.09 & 0.04 & 235.29 \\
\hline 2011 & 155.67 & 51.22 & 148.26 & 48.78 & 0 & 0 & 303.93 \\
\hline 2012 & 233.56 & 48.44 & 232.71 & 48.27 & 15.88 & 3.29 & 482.15 \\
\hline 2013 & 264.42 & 42.12 & 361.3 & 57.55 & 2.06 & 0.33 & 627.79 \\
\hline 2014 & 261.49 & 32.76 & 536.68 & 67.24 & 0 & 0 & 798.17 \\
\hline 2015 & 256.76 & 34.93 & 478.32 & 65.07 & 0 & 0 & 735.08 \\
\hline 2016 & 289.06 & 23.7 & 930.62 & 76.3 & 17.18 & 1.41 & 1219.68 \\
\hline \multicolumn{8}{|l|}{ Public Sector } \\
\hline 2005 & 215.36 & 45.22 & 254.94 & 53.53 & 5.92 & 1.24 & 476.22 \\
\hline 2006 & 222.36 & 53.75 & 182.79 & 44.18 & 8.55 & 2.07 & 413.7 \\
\hline 2007 & 225.19 & 57.96 & 156.03 & 40.16 & 7.32 & 1.88 & 388.54 \\
\hline 2008 & 248.74 & 61.48 & 150.07 & 37.1 & 5.74 & 1.42 & 404.56 \\
\hline 2009 & 242.01 & 53.75 & 205.28 & 45.59 & 2.97 & 0.66 & 450.26 \\
\hline 2010 & 304.96 & 50.89 & 291.14 & 48.58 & 3.14 & 0.52 & 599.24 \\
\hline 2011 & 401.86 & 53.82 & 342.35 & 45.85 & 2.43 & 0.32 & 746.64 \\
\hline 2012 & 557.8 & 47.57 & 588.26 & 50.17 & 26.56 & 2.27 & 1172.62 \\
\hline 2013 & 672.76 & 40.91 & 960.31 & 58.39 & 11.55 & 0.7 & 1644.61 \\
\hline 2014 & 798.99 & 35.16 & 1472.35 & 64.79 & 1.3 & 0.06 & 2272.64 \\
\hline 2015 & 966.11 & 34.69 & 1815.98 & 65.21 & 2.59 & 0.09 & 2784.68 \\
\hline 2016 & 1258.09 & 23.3 & 4141.48 & 76.7 & 34.82 & 0.64 & 5399.57 \\
\hline
\end{tabular}

\section{Growth of the GNPA and its determinants (2005-2016)}

Table shows the compound growth rate of the following variables for the period 2005 to 2016.Based on the following data the GNPA of major banks has been considerably increased after 2009. 


\section{An Economic Analysis of Non-Performing Assets of Banks in India}

Table - 2: Growth of the GNPA and its determinants (2005-2016)

\begin{tabular}{|c|c|c|c|c|c|c|c|c|c|c|}
\hline Year & SBI & PNB & IOB & IDBI & Central Bank & BOI & OBC & Dena Bank & Canara Bank & BOB \\
\hline 2005 & 12456.3 & 3741.3 & 1388.2 & 597 & 2621.4 & 3155.9 & 2513 & 1147.5 & 2370.6 & 3321.8 \\
\hline 2006 & 10375.8 & 3138.3 & 1227.6 & 1115.5 & 2684.2 & 2479.2 & 2116.3 & 949.4 & 1792.6 & 2390.1 \\
\hline 2007 & 9998 & 3391 & 1120 & 1232 & 2572 & 2100 & 1454 & 744 & 1493 & 2092 \\
\hline 2008 & 12837 & 3319 & 997 & 1565 & 2350 & 1931 & 1280 & 573 & 1416 & 1981 \\
\hline 2009 & 16345.6 & 2767.5 & 1923.4 & 1435.7 & 2316.5 & 2470.9 & 1058.1 & 620.8 & 2168 & 1842.9 \\
\hline 2010 & 17836.3 & 3214.4 & 3441.7 & 2129.4 & 2457.9 & 4481.2 & 1468.8 & 642 & 2504.5 & 2196.1 \\
\hline 2011 & $\begin{array}{c}25,326.2 \\
9\end{array}$ & 4379.4 & 2793.4 & 2784.7 & 2394.5 & 4356.6 & 1920.5 & 842.2 & 2981.8 & 2786.2 \\
\hline 2012 & $\begin{array}{c}39,676.4 \\
6\end{array}$ & 8689.9 & 3553.7 & 4551.4 & 7273.5 & 5169.7 & 3580.5 & 956.5 & 3890.1 & 3881.8 \\
\hline 2013 & $\begin{array}{c}51,189.3 \\
9\end{array}$ & $\begin{array}{c}13,465.7 \\
9\end{array}$ & 6608 & 6450 & 8456.2 & 8765.3 & 4184 & 1452.4 & 6260.2 & 7982.6 \\
\hline 2014 & $\begin{array}{c}61,605.0 \\
0\end{array}$ & $\begin{array}{c}18,880.0 \\
6\end{array}$ & 9020.5 & 9960.2 & 11500 & 11868.6 & 5617.9 & 2616 & 7570.2 & 11875.9 \\
\hline 2015 & $\begin{array}{c}56,725.0 \\
0\end{array}$ & $\begin{array}{c}25,694.8 \\
6\end{array}$ & 14922.5 & 12685 & 11873.1 & 22193.2 & 7666.2 & 4393 & 13040 & 16261.5 \\
\hline 2016 & $\begin{array}{c}98,172.8 \\
0\end{array}$ & $\begin{array}{c}55,818.3 \\
3\end{array}$ & 30048.6 & 24875.1 & 22720.9 & 49879.1 & 14701.8 & 8560.5 & 31637.8 & 40521 \\
\hline
\end{tabular}

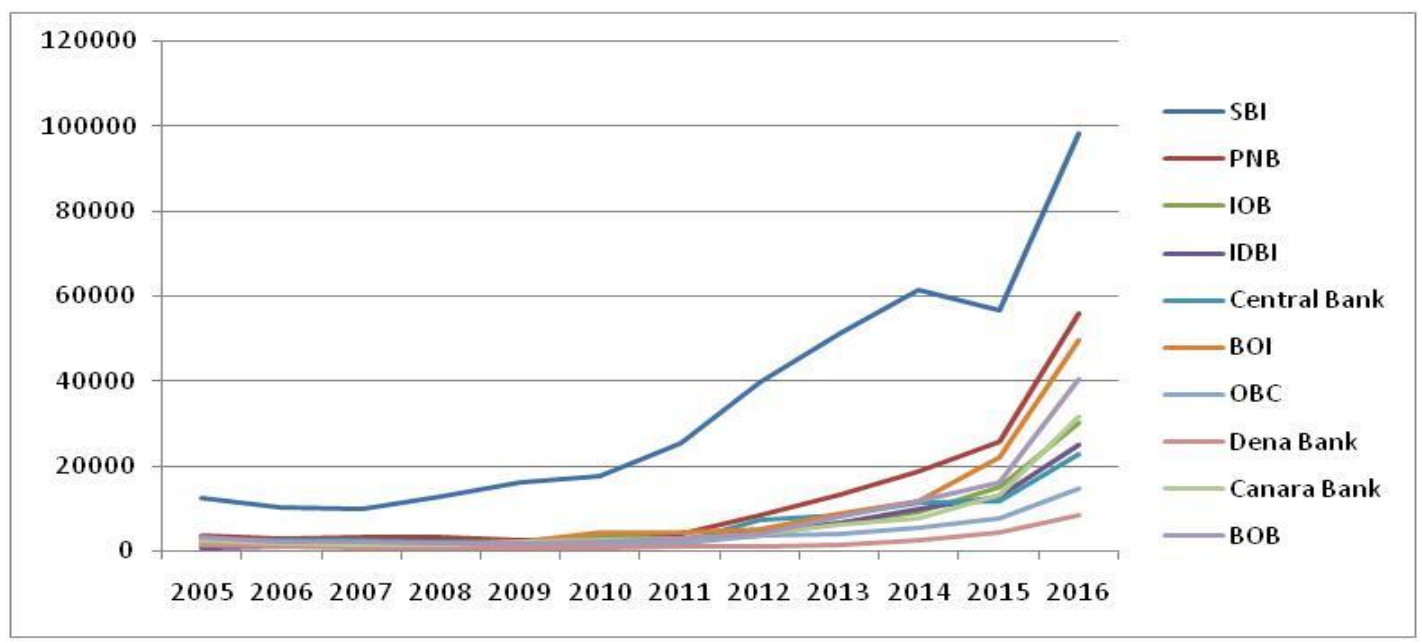

Figure - 2: Growth of GNPA

\section{FINDINGS}

Based on the data analysis and the interpretation the findings are listed as follows.

1. Public sector banks seem to be absolutely more hassled than private banks

2. The best 20 banks with maximum NPA ratios are public sector banks (PSBs)

3. The leading 2 banks, namely Indian Overseas Bank (36.2\%) and IDBI Bank (33.6\%) has NPA ratios of over $30 \%$

4. Indian Bank is the PSB with lowermost ratio of $7.21 \%$.

5. Top 10 banks have an NPA ratio of over $15 \%$ as of March 2016.

\section{LIMITATIONS OF THE READING}

The significant confines of study are as follows

1. The analysis of non-performing assets of SCB's is restricted to the Indian Bank and till the end of the year 2016.
2. The base for understanding non-performing assets is engaged from the Reserve Bank of India Publications.

3. NPAs are fluctuating with the time. The analysis is completed in the existing situation deprived of expectant upcoming growth.

\section{SUGGESTIONS}

1) Firming the pre-approval and after payout observing procedure by spending expertise

Banking Institutions necessity to observe their core and outward procedure and continually search for opportunities to strengthen alike, wherever expertise may stick is privilege. Data analytics and Machine Learning is the innovative catchword and has the prospective to offer intense perceptions in the NPA problem.

Published By:

Blue Eyes Intelligence Engineering \& Sciences Publication 
Our PSUs can advantage the amenities of data analytics to produce greatest current stage in the developments for cash flow group ability of a precise industry, historical proceedings of the debtors track an exact domain's development forecasts, validate the loan payment agenda etc. Interim assessments will also confirm a standing checked of the debtors, thus allowing banks to take defensive trials.

\section{2) Industry wise scheduling}

Convinced industries need to be scrutinized extra meticulously than other. RBI fiscal firmness report conditions that segments alike infrastructure, aviation, Iron and Steel, mining, fabrics make up $24.8 \%$ of total loans of Schedule banks but they grip an overwhelming $51.1 \%$ in over-all strained loans. Moving onward, bank scan deliberate on the positions of forming a debt evaluations quad will supply towards precise trades besides observe fresh loan bids and their position quo, consequently floating a red flag if any irregularities are identified.

\section{CONCLUSION}

The model predicted that if the current path was tramped, the issue of NPAs would mount into a major problem with severe consequences. To the extent that the Indian Banking industry is alarmed, it remained understood that debt amount to INR 7808 billion which is $4.94 \%$ of the Average Loans and Advances of all PSU banks. The predicted amount for SBI showed a forbidding picture where the bad debt would increase to INR 1479.21 billion, which would be $7.07 \%$ of the Typical Loans and Loans of SBI. The outcomes fact that the essential of the period is NPA regulator so as to evade the thoughtful costs that the upcoming clenches for us. We also roofed several grounds for NPAs and their conceivableness solution which might avert a loan after transforming it hooked on an NPA.

\section{REFERENCES}

1. Narula, S. and Singla, N. (2014) Empirical Study on Non-Performing Assets of Bank. International Journal of Advance Research in Computer Science and Management Studies, 2, No. 1.

2. Rogers, T., Fayman, A. and Campbell, N.D. (2011) Improving Recession Forecasts with Business Loan Data fromCommercial Banks. Journal of Applied Economics \& Policy, 30, 31.

3. Adair, A. and McGreal, S. (1988) The Application of Multiple Regression Analysis in Property Valuation. Journal ofValuation, 6, 57-67.

4. Hirst, M. (1970) Building and Operating a Forecasting Model: The Regression Analysis Approach. European Journalof Marketing, 4, 121-125

5. Brandon, C., et al. (1987) A Comparative Study of the Forecasting Accuracy of Holt-Winters and Economic Indicator

6. Models of Earnings per Share for Financial Decision Making. Managerial Finance, 13, 10-15

7. Ernst \& Young (2015) Unmasking India's NPA Issues - Can the Banking Sector Overcome This Phase? Ernst \&Young LLP, India, 508-089.

8. Sontakke, R.N. (2013) Trend Analysis of Non-Performing Asset in Scheduled Commercial Banks in India. InternationalJournal of Application or Innovation in Engineering \& Management (IJAIEM)

9. Selvarajan, B. and Vadivalagan, G. (2013) A Study on Management of Non-Performing Assets in Priority Sector Referenceto Indian Bank and Public Sector Banks (PSBs). Global Journal of Management and Business Research, 13, No.1.

\section{AUTHOR PROFILE}

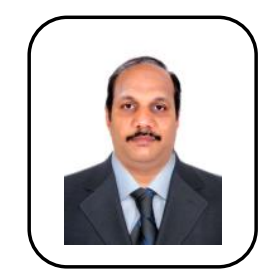

Sankara Narayanan K, completed M.Tech, M.B.A currently associated with the Department of Economics, Madras Christian College as a Full time Research Scholar. Having 16 years' experience in IT industry as a Software Consultant. His Current thesis involves an Econometrics analysis of Non-Performing Assets of Banks in India. His areas of interests are Artificial Intelligence, Data Science, Block Chain, Machine Learning and Financial Risk analytics. 